\title{
Plant Growth Promoting Abilities of Phosphate Solubilizing Bacteria Native from a High P-Sorbing Ultisol
}

\author{
Edith Mora ${ }^{1}$, Marcia Toro ${ }^{1}$, Edgar Flores ${ }^{1}$ and Danilo López-Hernández ${ }^{*}$ \\ ${ }^{1}$ Universidad Central de Venezuela, Instituto de Zoología y Ecología Tropical, Laboratorio de Agroecología, Apdo. \\ 47058, Caracas 1041A, Venezuela. \\ Email: danilo.lopez@ciens.ucv.ve
}

\begin{abstract}
P}$ adsorption isotherms were used to analyze P-sorption characteristics in a weathered slightly acid savanna ultisol. High $\mathrm{P}$ adsorption in this soil indicates significant $\mathrm{P}$ limitation in the experimental area. Microorganisms able to dissolve sparingly soluble phosphates of $\mathrm{Fe}$ and $\mathrm{Al}$ in the ultisol were studied in the rhizospheres of Galactia jussiaeana and Centrosema venosum, which showed Burkholderia cepacia as the dominant P-solubilizing bacteria species. Its promoting plant growth capacity was tested inoculating sterile Zea mays seeds; inoculated seeds germinated $100 \%$ while non-inoculated showed only $71 \%$ of germination. After three weeks, inoculated plants showed $28 \%$ increase in root length, higher biomass and foliar concentration of phosphate compared to noninoculated. Improvement of phosphate availability and a higher production of promoting root growth hormones by bacteria may explain these results. Burkholderia cepacia, native from tropical acid soils showed potential as a biofertilizer able to increase plant $\mathrm{P}$ nutrition in high $\mathrm{P}$ fixing soils.
\end{abstract}

Keywords: Acid soils, biofertilizers, burkholderia cepacia, plant growth promoting rhizobacteria (PGPR), phosphorus, sustainability

\section{Introduction}

The soils of the Orinoco savannas are, in general, well weathered due to the high temperature and relatively high precipitation occurring in the zone. Consequently, they are acid soils with low contents in $\mathrm{C}, \mathrm{N}, \mathrm{P}$ and as well low base contents in the exchangeable matrix [21]. Under increasing acidity, soil exchangeable aluminum $(\mathrm{Al}+3)$ tends to increase, in some cases to toxic levels, with a concomitant deficiency in available forms of phosphorus due to P-adsorption [17,21,40]. Currently, savanna's ecosystems are transformed into agricultural lands, which imply the use of important amount of soluble P-fertilizers to correct the high P-sorption capacities of savanna soils. Thus, in accordance with Casanova [6], about $70 \times 106$ ha of Venezuelan territory is affected by acidity where $\mathrm{P}$ is the main limiting element.

In natural conditions, most of tropical plants are adapted to different ecological niches associated to soil microorganisms. The diversity and abundance of microorganisms, plant and pedofauna influence different functions of the ecosystems which can play key roles in nutrient cycling and in the protection of the plant from environmental stress $[4,11,24]$. Within the microorganisms that may contribute to increasing nutrient availabilities, phosphate solubilizing bacteria are outstanding. Many of these bacteria have Plant Growth Promoting (PGP) properties that play a significant role in soil $[2,13,38]$. Plant Growth Promoting Rhizobacteria (PGPR) are soil free bacteria able to colonize and live in the rhizosphere, where they contribute to the growth and development of the plant system through different activities such as: increasing the solubility of inorganic nutrient elements (e.g. P, K,Ca) from insoluble sources, fixing atmospheric N2, reducing root pathogens (by antagonism or competition), and finally, producing plant growth regulating substances (vitamins, auxins, cytokinins, and gibberellins) that contribute to increasing root growth $[2,8,13]$.

It is well known that some soil microorganisms, including PGPR, have great potential to contribute to amending local fertility problems; consequently, they might be used as biofertilizers [3,38]. Biotechnologies with those biological agents, when found, may be applied at greenhouse level in the production of good quality seeds or in the massive generation of plants $[4,11,48]$. Therefore, at the level of agroecosystems, the finding, isolation and sustainable management of those microorganisms is an 
important desideratum, since they favor ecosystem plant nutrition and consequently, they may be used to reduce the application of high commercial fertilizer doses [47].

In a previous contribution [25], it was reported a survey of the presence of some beneficial plantmicroorganism associations in a typical Trachypogon savanna, with particular emphasis on arbuscular mycorrhiza populations, symbiotic N-fixing bacteria and free living microorganisms that stimulate plant growth through phosphate solubilization.

In this contribution we analyze, firstly, $\mathrm{P}$ parameters of the savanna soil previously studied in a more detailed form, and secondly, from the original plant survey studied, we examined a selection of effective local bacteria strains that will be assayed to determine their capacity to solubilize phosphates, promote plant growth, enhance germination and stimulation of root growth in Zea mayz; attributes that can be used to define those PGPR as potential biofertilizers.

\section{$2 \quad$ Materials and Methods}

The study was carried out at "Estación Experimental La Iguana" (EELI), located in Guárico State in Northeastern Venezuela $\left(8^{\circ} 25^{\prime} \mathrm{N}\right.$ and $\left.65^{\circ} 24^{\prime} \mathrm{W}\right)$. EELI is under the influence of the Orinoco River watershed and corresponds to representative savannas of the Venezuelan Central Plains. These savannas are dominated by T. plumosus (Poaceae) with the presence of isolated trees and shrubs such as Curatella americana (Dellineaceae), Copernicia tectorum (Palmae), Byrsonima crassifolia (Malpigheaceae) and Bowdichia virgilioides (Papiloneaceae). The climate of the zone is markedly tropical isothermic, with a mean annual precipitation of $1342 \mathrm{~mm}$, most of which falls during the rainy season (May to October), and a mean annual temperature of $27.9^{\circ} \mathrm{C}$. EELI has edaphic substrates different in age and genesis [32].

\subsection{Soil Sampling and P Characterization}

In the experimental site, selected triplicate soil samples of an ultisol were collected. Each replicate was a composite sample integrated by eight soil subsamples collected at random from the $0-10 \mathrm{~cm}$ of soil layer and sieved through a $2-\mathrm{mm}$ mesh.

\subsection{Determination of Phosphate Sorption Isotherm}

The phosphate adsorption isotherm of the ultisol was obtained by a modification of the method described by López-Hernández et al. (1986). Phosphate was adsorbed on $0.5 \mathrm{~g}$ soil samples by shaking them for $24 \mathrm{~h}$ with phosphate solutions (KH2PO4) which give 0, 20, 40, 50, 60, 80 y $100 \mu \mathrm{gP} / \mathrm{g}$ in 0.02 $\mathrm{M} \mathrm{KCl}$. After phosphate adsorption the $\mathrm{P}$ concentration in the clear solution was determined [26].

\subsection{Sampling of Rhizospheric Soils and Selection of Plants with Abundance of PSB}

In order to describe, characterize and quantify the association of native plants with Phosphate Solubilizing Bacteria (PSB) living in the rhizosphere of the studied soil plants, in an experimental area of $260 \mathrm{~m} \times 77 \mathrm{~m}$ at EELI, three equidistant transects were located [24]. Seven plots of $1 \mathrm{~m} 2$ were set up, $10 \mathrm{~m}$ apart, at both sides of the three transects during the middle of the rainy season (July). All plants inside the 21 plots were collected and preserved for later identification.

Rhizospheric soil and roots from each plant were collected from the root zone $(0-20 \mathrm{~cm})$ by previously removing plant debris from the soil surface. Soil located at $1 \mathrm{~cm}$ from the roots was used to isolate phosphate solubilizing bacteria and to measure rhizospheric $\mathrm{pH}$. pH of bulk and rhizospheric soil samples were determined in a $\mathrm{KCl} 1 \mathrm{M}$ 1:1 soil solution ratio [1].

\subsection{Isolation and Identification of Phosphate Solubilizing Bacteria}

One g of fresh rhizospheric soil was serial diluted and $0.1 \mathrm{~mL}$ of dilution was added to Petri dishes with the following selective media: standard phosphate-solubilizing medium (PS) [50] and yeast extractdextrose medium (YED) [31], each containing one of the following phosphorus compounds: dicalcium phosphate (CaHPO4), aluminum phosphate (AlP04) and iron phosphate (FeP04). After bacteria 
development, colonies showing a surrounding halo of clearance, or a change of color surrounding the colony (from purple to yellow), were selected as phosphate solubilizers or acidifiers of the surrounding environment, respectively $[23,42,50]$. Halo clearance showing solubilization capacity of bacteria over Ca, $\mathrm{Al}$ and $\mathrm{Fe}$ phosphates was measured in three colonies of the bacteria growing in each media; data are mean of three halos.

From the total universe of native plants analyzed, we will choose those which showed a high proportion of PSB in relation to the total bacteria number since we believe that the presence of PSB in the rhizosphere of those species constitutes an important starting material to look for potential biofertilizers $[24,26]$.

\section{$2.5 \quad$ Identification of Bacteria}

Once the colonies able to solubilize phosphates were isolated from the plant rhizosphere, different biochemical tests were applied in order to identify and characterize the bacteria [22]. Moreover, to assess them as PGPR, experiments were conducted to determine their capacity to enhance germination, promote plant growth and stimulation of the root and shoot growth in Zea mayz (Turén variety) [14, $29]$.

After the colonies with P-solubilizing capacity were purified, we continued with morphological characterization and biochemical tests for identification [22]. Subsequently, API® reference range identification systems and confirmatory tests for definitive identification were applied $[23,30]$.

\subsection{Testing of the Plant Growth Promotion}

Promotion of germination: Seeds of maize were sterilized superficially with sodium hypochlorite (10\%) and uniformly distributed into sterile Petri dishes. $1 \mathrm{~mL}$ of PSB culture was applied to each seed with a 108cells/mL density [31,42]. Control treatments did not carry the bacterial culture, but medium culture without bacteria. Each treatment presented five repetitions. After seven days, the percentage of germination and the size of the radicles were measured.

Promotion of radical growth: Pots were filled with steamed sterilized sand, and, then, one sterilized maize seed per pot was introduced. Four days later the emerged seedlings were inoculated with $1 \mathrm{~mL}$ of PSB culture (108 cells $/ \mathrm{mL})$. Inoculation was repeated a week later. Control did not carry the bacterial inoculum but the medium culture without bacteria. All treatments were irrigated with Hewitt's nutritive solution [8]. The experiment took place in greenhouse conditions of sterility for 21 days. After this time the plants were cut, the length of root was measured by the Newman method [27] modified by Tennant [41]. Each treatment had 5 repetitions.

\subsection{Plant Determinations}

After harvesting, plant materials were washed out with distilled water and dried at $60^{\circ} \mathrm{C}$ for 24 hours; then the biomass was determined. Phosphorus foliar content was quantified after an acid digestion with a binary mixture (hydrochloric and perchloric acids) [26].

\subsection{Statistical Analysis}

A test of homogeneity by applying a one-way ANOVA (95\% confidence) was performed to analyze the plant variables: $\mathrm{P}$ content, root length and stem dry weight. Mean comparisons were made between inoculated and non-inoculated treatments. Significant differences are given by the standard deviations.

\section{$3 \quad$ Results and Discussion}

\subsection{General Characteristics of the Studied Soil}

The soil used for the determination of the adsorption isotherm is slightly acid, with low natural fertility and low cation exchange capacity (CEC); main soil characteristics were already presented by Lopez 
Gutierrez et al. [15]. The organic matter and nitrogen contents were moderately corresponding to a $\mathrm{C} / \mathrm{N}$ ratio of 23.6 (Table 1). The total $\mathrm{P}$ content $(\mathrm{Pt}$ ) and $\mathrm{P}$ availability (P-NaHCO3) were also low (Table 1). On the contrary, this ultisol presented a high amount of exchangeable iron and aluminium and, according to the $\mathrm{P}$ adsorption isotherm (Fig. 1), a very high P-sorption capacity; a similar result has been already presented in an ultisol corresponding to the serie Tamaca, Venezuela, with high concentrations of exchangeable aluminum and free iron [19].

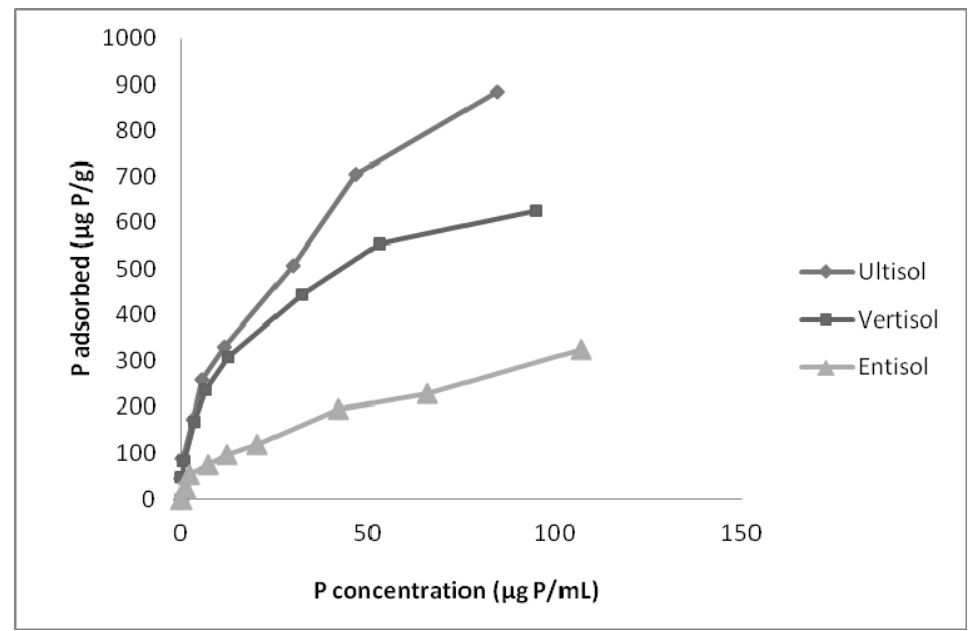

Figure 1. Phosphate adsorption isotherms in selected soils of Estación Experimental La Iguana

The high $\mathrm{P}$ adsorption in the soil herein analyzed, seems to be more related to the Fe content, than to the exchangeable aluminum and is concomitant with their low available $\mathrm{P}$ content (Table 1).

Table 1. General characterization of a savanna ultisol in Estación Experimental La Iguana. Modified from LópezGutiérrez et al [15].

\begin{tabular}{|c|c|}
\hline Soil Characteristic & \\
\hline $\mathrm{pH}$ & 5.4 \\
\hline Sand $(\%)$ & 73.2 \\
\hline Silt (\%) & 13.2 \\
\hline Clay (\%) & 13.6 \\
\hline Texture & Sandy loam \\
\hline P-Total (mg kg-1) & 102.1 \\
\hline P-NaHCO3 (mg kg-1) & 2.6 \\
\hline $\mathrm{N}(\%)$ & 0.11 \\
\hline $\mathrm{C}(\%)$ & 2.36 \\
\hline $\mathrm{Fe}(\mathrm{mg} \mathrm{kg}-1)$ & 109.6 \\
\hline $\mathrm{Al}(\mathrm{cmol} \mathrm{kg}-1)$ & 0.70 \\
\hline $\mathrm{H}(\mathrm{cmol} \mathrm{kg}-1)$ & 0.20 \\
\hline $\mathrm{Ca} \quad(\mathrm{cmol} \mathrm{kg}-1)$ & 1.88 \\
\hline $\mathrm{Mg}(\mathrm{cmol} \mathrm{kg}-1)$ & 2.41 \\
\hline $\mathrm{Na} \quad(\mathrm{cmol} \mathrm{kg}-1)$ & 0.09 \\
\hline $\mathrm{K}(\mathrm{cmol} \mathrm{kg}-1)$ & 0.22 \\
\hline CEC (cmol kg-1) & 8.28 \\
\hline
\end{tabular}

In Figure 1, for comparative reasons, the adsorption isotherm of the ultisol is presented, together with two isotherms corresponding to a very low sorbing entisol and a moderate P-retention vertisol, located in the same savanna zone at EELI. All these aspects indicate a significant $\mathrm{P}$ limitation in the 
experimental area covered by the ultisol. A situation that might make particularly relevant the influence of the root environment (and associated processes) as important locus for mechanisms of biological origin which help to cope with $\mathrm{P}$ deficiencies $[21,45,46]$.

As far as the pHs of the rhizospheric soils are concerned, their values were always lower than in the bulk soil with a difference ranging from 0.13 to 0.98 for Sida sp. and Stylosanthes sp., respectively (Table 2), which indicate the influence that may have the acidification of the root environment and their associated processes such as organic acid secretions on the improvement of available $\mathrm{P}[5,18,20,37]$.

\subsection{Isolation of Phosphate Solubilizing Bacteria (PSB)}

The isolation of PSB was done in a total of 22 rhizospheres corresponding to the most important plant species present in the experimental area (Table 2); from the total, eight rhizospheres were positive to the presence of PSB (Figure 2).

Table 2. $\mathrm{pH}(\mathrm{KCl})$ of rhizospheric soils of chosen plant species in the experimental area and differences between $\mathrm{pH}$ of bulk (4.86) and rhizospheric soils

\begin{tabular}{l|l|l}
\hline Species & $\mathbf{p H}$ rhizospheric soil & $\Delta \mathbf{p H}$ \\
\hline Desmodium sp. & 3.93 & 0.93 \\
\hline Indigosfera pascuorum & 4.59 & 0.27 \\
\hline Phaseolus vulgaris & 4.14 & 0.72 \\
\hline Stylosanthes sp. & 3.88 & 0.98 \\
\hline Galactia jussiaeana & 4.16 & 0.70 \\
\hline Mimosa pudica & 4.20 & 0.62 \\
\hline Trachypogon sp. & 4.18 & 0.68 \\
\hline Panicum sp. & 4.06 & 0.70 \\
\hline Rynchospora cephalotes & 4.05 & 0.81 \\
\hline Rychospora barbata & 3.91 & 0.95 \\
\hline Fimbristylis sp. & 4.27 & 0.59 \\
\hline Polygala glochiata & 4.09 & 0.77 \\
\hline Hyptis sp. & 3.99 & 0.87 \\
\hline Sida sp. & 4.73 & 0.13 \\
\hline Borreria sp. & 4.22 & 0.64 \\
\hline Diodia teres & 4.06 & 0.80 \\
\hline Ruellia geminiflora & 4.56 & 0.30 \\
\hline Aeschynomene sp. & 4.40 & 0.46 \\
\hline Cassia cultrifolia & 4.30 & 0.56 \\
\hline Centrosema venosum & 4.35 & 0.51 \\
\hline Desmodium sp. & 3.93 & 0.93 \\
\hline Indigosfera pascuorum & 4.59 & 0.27 \\
\hline & & \\
\hline
\end{tabular}

When analyzing the total amount of bacteria colony forming units in relation to PSB, we found that the rhizospheres of Centrosema venosum and Galactia jussiaeana present a high proportion of PSB in relation to the total bacteria (ToB) number ( $75 \%$ and $43 \%$, respectively), therefore the presence of PSB in the rhizosphere of those two species might constitute an important starting material to look for potential biofertilizers (Figure 2). 


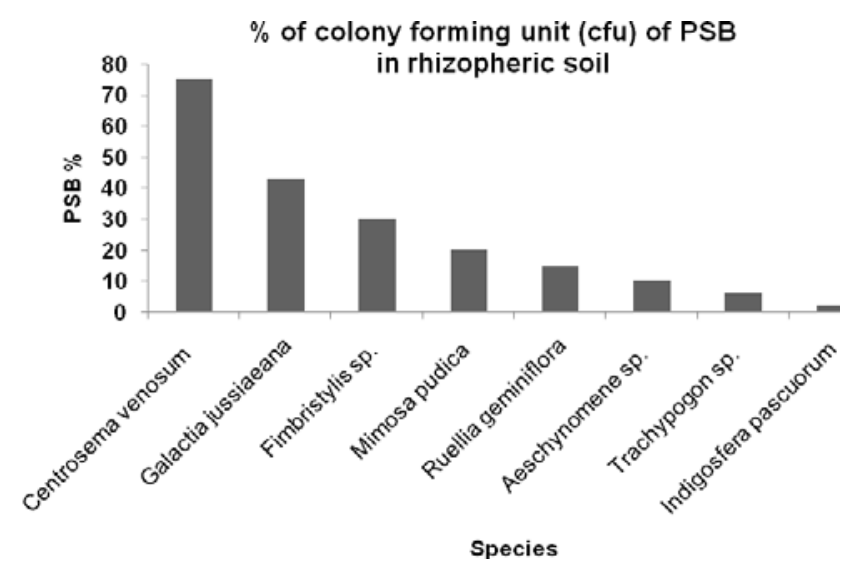

Figure 2. Percentage of PSB (\% cfu PSB) respect to total bacterial counts (cfu ToB) in rhizopheric soil of field plants.

\subsection{Isolation and Identification of PGPR}

From the rhizosphere of Centrosema venosum and Galactia jussiaeana, bacteria strains were isolated based on their capacity to solubilize phosphates of calcium, iron and aluminum.

According to the morphological characteristics of bacteria in different media and the preliminary biochemical tests, we concluded the predominance of Burkholderia cepacia in the studied rhizospheres. The later tests with specific galleries [35] corroborated such identification. Burkholderia cepacia, the phosphate solubilizing bacteria isolated, presents the capacity to acidify the medium and to solubilize inorganic phosphate forms (Table 3).

Table 3. Capacity of solubilization of phosphates of calcium, iron and aluminum and acidification of the surrounding media by Burkholderia cepacia.

\begin{tabular}{l|l|l|l|l|l}
\hline & & & \multicolumn{4}{|l}{ Halo average diameter of three colonies (mm) } \\
\cline { 4 - 6 } Medium & Initial pH & Final pH & CaHP04 & Al PO4 & Fe PO4 \\
\hline & & & & & \\
YED [31] & 7.0 & 6.0 & 6 & ----- & --- \\
\hline & & & & 9 & 10 \\
\hline
\end{tabular}

\subsection{Testing of the Plant Growth Promotion Ability}

Inoculation of Burkholderia cepacia to Zea mayz seeds favored $100 \%$ the germination, while in the control treatment (without bacteria) the germination was $71 \%$; the radicle length averaged $2.17 \mathrm{~cm}$ in the inoculated seeds and $0.72 \mathrm{~cm}$ in the control treatment. This indicates the important increase in growth together with a clear promotion of germination of the radicle in inoculated seeds of Zea mayz.

Tests for growth promotion showed that after 3 weeks of inoculation, plants inoculated with Burkholderia cepacia showed higher values for root length (28\%), biomass (52\%) and foliar P content $(50 \%)$ over non-inoculated treatments. Increases are statistically significant for biomass and foliar $\mathrm{P}$ content, whereas in the case of the root length due to the high variability of results there was not significance between means. The results from growth parameters allow to characterize Burkholderia cepacia as a maize growth promoter bacterium (PGPR) under greenhouse conditions.

Our results agree with Torriente [44], who noted that B. cepacia was able to solubilize inorganic phosphates and produce $25 \%$ yield increases in sugar cane. Our results are also in line with Moreno and Galvis [25], who found that a strain, identified as B.cepacia, promoted $30 \%$ of germination and root growth in maize over non inoculated controls. 
Table 4. Parameters of plant growth of Zea mayz inoculated or not with Burkholderia cepacia.

\begin{tabular}{l|l|l|l}
\hline & $\begin{array}{l}\text { P foliar content } \\
(\mu \mathrm{g} / \text { plant })\end{array}$ & $\begin{array}{l}\text { Biomass } \\
(\mathrm{g} / \mathrm{plant})\end{array}$ & $\begin{array}{l}\text { Root length } \\
(\mathrm{m} / \mathrm{plant})\end{array}$ \\
\hline Inoculated plants & $5.87(1.20)$ & $0.420(0.09)$ & $7.480(0.88)$ \\
\hline Non inoculated plants & $3.09(1.36)$ & $0.276(0.12)$ & $5.474(2.24)$ \\
\hline
\end{tabular}

Data are average of 5 repetitions, and standard deviations are in brackets.

In acid soils phosphorus is rendered unavailable due to their precipitation and/or adsorption as phosphates of iron and aluminum [17]. Therefore, phosphorus deficiency is an edaphic characteristic most common in the acid and well weathered tropical soils. The soil solution is usually enriched in $\mathrm{P}$ through the chemical solubilization of inorganic sources of phosphates, or through the microbial mineralization of organic phosphates, both mechanisms are particularly important in well weathered savanna soils [12,15,16,33]. According to Sanchez and Salinas [36], 82\% of the extension of the tropical American land is P-limited; therefore, it is important to highlight the ability of soil microorganisms such as B. cepacia capable of solubilizing the main types of unavailable phosphates present in well weathered acidic soils, through its capacity to acidify the surrounding environment (Table 3). This ability may be due to generation of organic acids which release inorganic phosphate sources, or through the competition of organic acids with orthophosphate for P-sorbing places [10,20, 28].

\subsection{Diversity of Burkholderia Cepacia in the Environment}

B. cepacia possess an unusually complex and plastic genome which may favor their adaptation to different environments, and it is not surprising that the different strains of the complex are found in habitats as diverse as soil, water, plant, and animal surfaces and rhizosphere. This remarkable versatility is well exemplified by the wide array of properties that B. cepacia possess [34]. Thus, it is now well settled that B. cepacia can act both as plant growth promoting biocontrol and bioremediation agent and as opportunistic human pathogen in immune-compromised patients [39, 43]. Despite the useful properties those organisms may offer to bioremediation or as an alternative to pesticides and fertilizer in agriculture, commercial application has been hampered by the risk B. cepacia complex may pose to human health. In conclusion, it seems possible that this bacteria due to its diversity can play an important role in ameliorating agriculture practices in tropical ecosystems, nonetheless, before using it as mass inoculum previous tests should be done, in order to discard harmful effects on human health $[38,39]$.

\section{Conclusions}

The results obtained show Burkholderia cepacia as a bacterium capable of promoting the growth and development of plants. Although in this work the bacteria effect was only tested on Zea mayz, its promoting capacities must be proved on other tropical crops. Characterization and isolation of Burkholderia cepacia as promoter bacteria of plant growth allows us to suggest its use as a biofertilizer for tropical crops developed in acidic soils. Burkholderia cepacia showed the ability to promote the growth, germination, elongation of root and production of biomass of Zea mayz. These features indicate its potential application as biofertilizer and/or as biological control in crops of agricultural interest for the acidic soils of savanna. However more tests should be done, in order to discard any harmful effects on human and environmental health.

Acknowledgements. We would like to express our acknowledgements to 'Fondo Nacional de Ciencia y Tecnología' (Proyecto S1-2000000649) and to 'Consejo de Desarrollo Científico y Humanístico-UCV' (Proyecto 03.31.4109.98) for partially financing the study. Finally, we thank José Hernández, Mauricio Ramia and Shingo Nozawa for their assistance in the identification of plant samples. We would like to acknowledge Dr. Rosvel Bracho from the Biology Department, University of Florida, Gainesville, USA, 
for his comments and revision of an early version of the manuscript. We are also indebted to an anonymous referee for the editing and critical revision of the manuscript.

\section{References}

1. J. M. Anderson and J. S. Ingram, "Tropical soil biology and fertility: a handbook of methods, " CAB International, UK.1993.

2. H. Antoun and D. Prévost, "Ecology of plant growth promoting rhizobacteria," in Z. A.Siddiqui (ed.) PGPR: Biocontrol and Biofertilization. Springer, 2005, pp. 1-38.

3. P. N. Bhattacharyya and D. K. Jha, "Plant growth-promoting rhizobacteria (PGPR): emergence in agriculture," World J Microbiol Biotechnol, vol.28: pp. 1327-1350, 2012.

4. G. D. Bowen and A. D. Rovira,"The rhizosphere and its management to improve plant growth," Advances in Agronomy, vol.66: pp 1-102,1999.

5. L. Chapuis-Lardy, R. C. Le Bayon, M. Brossard, D. Lopez-Hernandez and E. Blanchart, "Role of soil macrofauna in P cycling," in E. K, Bünemann, A. Oberson, E. Frossard (eds.) Phosphorus in Action -- Biological Processes in Soil Phosphorus Cycling, Biology Series 26, Springer Soil. Springer, 2011, pp. 199-213.

6. E. Casanova, "Limitación, potencial y uso agrícola de las tierras en Venezuela," in Introducción a la ciencia del suelo. Universidad Central de Venezuela. Consejo de Desarrollo Científico y Humanístico, 1996.

7. R. Castro-González, L. Martínez-Aguilar, A. Ramírez-Trujillo, P. Estrada-de los Santos and J. Caballero-Mellado, "High diversity of culturable Burkholderia species associated with sugarcane, " Plant Soil, vol. 345: 155-169, 2011.

8. B. R.Glick, "The enhancement of plant growth by free-living bacteria," Can J Microbiol, vol. 41: 109-117,1995.

9. E. J. Hewitt, "Sand and water culture methods used in the study of plant nutrition," CABI. Farnham Royal, 1966.

10.P. Jeffries and J. M. Barea, "Arbuscular Micorriza -a key component of sustainable plant-soil ecosystems," The Mycota, vol. 4: 95-113,2000.

11.L. Kellogg, S. Bridgham and D. López-Hernández, " Organic phosphorus mineralization. A comparison of isotopic and non-isotopic methods," Soil Sci Am Jour, vol. 70: 1349-1358, 2006.

12.J.W. Kloepper, "Plant-growth-promoting rhizobacteria as biological control agents" in F. B. Jr Metting, (ed.) Soil Microbial Ecology, Marcel Dekker Inc, 1993, pp.255-273.

13.J. W. Kloepper, R. Lifshitz, R. M. Zablotowicz, "Free-living bacterial inocula for enhancing crop productivity," Trends Biotechnology, vol. 7: 39-43,1989.

14.J. C. López-Gutiérrez, M.Toro and D. López-Hernández," Seasonality of organic phosphorus mineralisation in the rhizosphere of the native savanna grass, Trachypogon plumosus,"Soil Biol. Biochem, vol. 36: 1675-1684,2004a.

15.J. C. López-Gutiérrez, M. Toro and D. López-Hernández," Arbuscular mycorrhyza and enzymatic activities in the rhizosphere of Trachypogon plumosus in three acid savanna soils," Soil Agric and Environ,vol. 103: 405-411, $2004 \mathrm{~b}$.

16.D. López-Hernández," La Química del Fósforo en Suelos Ácidos, " Casa Editora: Ediciones de la Biblioteca. Universidad Central de Venezuela.1977.

17.D. López-Hernández and D. Flores, " La desorción de fosfatos en suelos. Implicaciones fisioecológicas en el proceso," Acta Científica Venezolana, vol. 30: 23-35, 1979.

18.D. López-Hernández, I. Coronel and L. Alvarez, " Uso de la isoterma de adsorción para evaluar requerimientos de fósforo. I. Isoterma de adsorción de los suelos," Turrialba, vol. 31: 169-180,1981.

19.D. López-Hernández, G. Siegert and J. V. Rodríguez, "Competitive adsorption of phosphate with malate and oxalate by tropical soils," Soil Sci Soc Amer J, vol. 50: 1460-1462, 1986.

20.D. López-Hernández, M. Toro and J. C. López-Gutiérrez, "Role of microbial, enzymatic and pedofauna activities in making good the adaptation of Trachypogon to phosphorus depleted environments," in M. Miransari (ed). Soil Nutrients. Nova Science Publishers, 2011. pp. 93-126.

21.J. M. Mac Faddin, "Pruebas bioquímicas para la identificación de bacterias de importancia clínica," Editorial Panamericana. 1980.

22.E. Mora and M. Toro, "Estimulación del crecimiento vegetal por Burkholderia cepacia, una cepa nativa de suelos ácidos de sabanas venezolanas," Agronomía Tropical, vol. 57: 123-128, 2007. 
23.E. Mora, M. Toro and D. López-Hernández, "A survey of arbuscular mycorrhizae, Rhizobium and phosphate solubilizing bacteria in low fertility savanna soils in Central Venezuela (Estación Experimental La Iguana), " in Miransari M. (ed.) Soil Microbiology. Nova Science Publishers Inc. 2012, pp. 98-112.

24.L. Moreno and F. Galvis, "Potencial biofertilizante de bacterias diazótrofas aisladas de muestras de suelo rizosférico," Pastos y Forrajes, vol. 36: 33-37, 2013.

25.J. Murphy and J. P. Riley, "A modified single solution method for the determination of phosphate in natural waters," Analytical Chimica Acta, vol. 26: 31-36, 1962.

26.E. I. Newman, "A method of estimating the total length of root in a sample," J Appl Ecol, vol. 3: 139-145, 1966.

27.E. Osorio, "Estudio de los ácidos orgánicos producidos por microorganismos del suelo y su aplicación en la solubilización de fosfatos inorgánicos," Trabajo Especial de Grado. Escuela de Química, Facultad de Ciencias, Universidad Central, Venezuela. 2007.

28.K. K. Pal, R. Dey, D. M. Bhatt and S. M. Chauhan, "Plant growth promoting fluorescent pseudomonads enhanced peanut growth, yield and nutrient uptake," available http://www.ag.auburn.edu/ mlowens/argentina/pdfmanuscripts/pal.pdf. 1999.

29.R. Patrick, E. Baron, P. M. Faller, F. Tenover and R. Yolken," Manual of Clinical Microbiology," 7 edition. American Society for Microbiology, 1999.

30.A. Peix, A. Rivas-Boyero, P. F. Mateos, C. Rodríguez-Barrueco, E. Martínez-Molina and E. Velázquez, "Growth promotion of chickpea and barley by a phosphate solubilizing strain of Mesorhizobium mediterraneum under growth chamber conditions," Soil Biol Biochem, vol. 33: 103- 110,2001.

31.M. E. Ponce, V. González, J. Brandín and M. E. Ponce," Análisis de la vegetación asociada a una toposecuencia en los Llanos Centro-Orientales de Venezuela," Ecotropicos, vol. 7: 11- 22,1994.

32.E. Purnomo, A. Mursyid, M. Syarwani, A. Jumberi, T. Hashidoko, Y. Hasegawa, S. Honma and M. Osaka, "Phosphorus Solubilizing Microorganisms in the Rhizosphere of Local Rice Varieties Grown without Fertilizer on Acid Sulfate Soils," Soil Sci Plant Nut, vol.51: 679- 685, 2005.

33.A. Ramette, J. LiPuma and J. M. Tiedje, "Species Abundance and Diversity of Burkholderia cepacia Complex in the Environment," Appl Environ Microbiol, vol 71(3): 1193-1201, 2005.

34.A. E. Reynaud, B. Coude Du Foresto and A. L. Courtieu, "Etude comparative de diverses galeries API pour l’identificaction des bacteries gram negative," Ann Biol Clin, vol. 46: 259- 262, 1988.

35.P Sánchez and J. Salinas, "Suelos ácidos y estrategias para su manejo con bajos insumos en América Tropical," SCCS.1983.

36.G. Schaller, "pH changes in the rhizosphere in relation to the pH-buffering of soils," Plant Soil, vol. 97: 439- 444, 1987.

37.S. Sheraz Mahdhi, G. I. Hassan, S. A. Samoon, H. A. Rather, S. A. Dar and B. Zehra, "Bio-fertilizers in organic agriculture," Journal of Phytology, vol. 2: 42--54. 2010.

38.S. Tabacchioni, A. Bevivino, C. Dalmastri, L. Chiarini, "Burkholderia cepacia complex in the rhizosphere: a minireview," Annals of Microbiology, vol. 52: 103-117, 2002.

39.K. Tan and W. Keltjens, "Interaction between aluminium and phosphorus in sorghum plants. II. Studies with the aluminium tolerant sorghum genotype," Plant Soil, vol. 124: 25—32, 1995.

40.D. Tennant, "A test of modified line intersect method of estimating root length," J Ecol, vol. 63: 995-1001, 1975.

41.G. V. Thomas and M. V. Shantaram, "Solubilization of inorganic phosphates for bacteria from coconut plantation soils," Journal of Plantation Crops, vol. 14: 42-48, 1986.

42.L. Torbeck, D. Raccasi, D. Guilfoyle, R.L. Friedman and D. Hussong, "Burkholderia cepacia: This Decision Is Overdue, " PDA J Pharm Sci and Tec, vol 65, 535-543, 2011.

43.D. Torriente, "Aplicación de bacterias promotoras del crecimiento vegetal en el cultivo de la caña de azúcar. Perspectivas de su uso en Cuba,". Cultivos Tropicales, vol. 31: 19-26, 2010.

44.M. Toro, R. Azcón and J. M. Barea, "Improvement of arbuscular mycorrhiza development by inoculation of soil with phosphate-solubilizing rhizobacteria to improve rock phosphate bioavailability (32P) and nutrient cycling," Appl. Environ. Microbiol, vol.63: 4408-4412, 1997.

45.M. Toro and D. López-Hernández, "Potencialidades del manejo de las Micorrizas Arbusculares para el desarrollo sostenido de los sistemas agrícolas de bajos insumos del ecotono sabana-bosque amazónico," in R J. Carrillo (ed.) Memorias del IV Congreso Interamericano sobre el medio ambiente, Caracas, Venezuela. Colección Simposia, 1998. pp. 222--227. 
46.M. Toro, R. Azcón and J M. Barea, "The use of isotopic dilution techniques to evaluate the interactive effects of Rhyzobium genotype, mycorrhizal fungi, phosphate solubilizing rhizobacteria and rock phosphate on nitrogen and phosphorus acquisition by Medicago sativa," New Phytol, vol. 138: 265-273,1998.

47.M. Toro, I. Bazó and M. López,"Micorrizas Arbusculares y bacterias promotoras de crecimiento vegetal, biofertilizantes nativos de sistemas agrícolas bajo manejo conservacionista," Agronomía Tropical, vol. 58: 78-83, 2008.

48.J. Vessey, "Plant growth promoting rhizobacteria as biofertilizers," Plant Soil, vol. 255: 571- 586, 2003.

49.C. L. Wenzel, A. E. Ashford and B. A. Summerell, "Phosphate solubilizing bacteria associated with proteoid roots of seedlings of waratah [Telopea speciosissima (Sm.) R.Br.]," New Phytol, vol. 128: 487- 496, 1994. 